Вестник ВГУ. Серия: Право

УДК 340.13

DOI https://doi.org/10.17308/vsu.proc.law.2020.3/2982

\title{
ИНФОРМАЦИОННЫЕ ТЕХНОЛОГИИ В СИСТЕМАТИЗАЦИИ ИНФОРМАЦИОННОГО ЗАКОНОДАТЕЛЬСТВА РЕСПУБЛИКИ БЕЛАРУСЬ
}

\author{
Ю. Г. Иванцова
}

Институт повышения квалификации и переподготовки кадров учреждения образования «Гродненский государственный университет илени Янки Купаль»"

Поступила в редакцию 30 ноября 2019 г.

\begin{abstract}
Аннотация: дается характеристика основньх инфорлационных технологий при проведении систелатизации инфорлационного законодательства Республики Беларусь. Исследована роль поискового навигатора, Единого правового классификатора Республики Беларусь, Свода законов Республики Беларусь в электронной фборме, словаря юридических терминов на белорусскол, русскол и английскол языках.

Ключевые слова: Единый правовой классификатор Республики Беларусь, инфборлаиионное законодательство Республики Беларусь, правовой навигатор, систематизация законодательства, Свод законов Республики Беларусь, словарь юридических терлинов; совершенствование законодательства.
\end{abstract}

\begin{abstract}
: the author gives a description of the main information technologies during the systematization of the information legislation of the Republic of Belarus. The role of the search navigator, the Unified Legal Classifier of the Republic of Belarus, the Code of Laws of the Republic of Belarus in electronic form, and the Dictionary of Legal Terms in Belarusian, Russian and English are investigated. Key words: Unified legal classifier of the Republic of Belarus, information legislation of the Republic of Belarus, legal navigator, systematization of legislation, Code of Laws of the Republic of Belarus, dictionary of legal terms, improvement of legislation.
\end{abstract}

За время существования суверенной Республики Беларусь была создана развитая система информационного законодательства, представленного в форме комплексного массива нормативных правовых актов со слабыми предметно-функциональными связями между его частями. Усиление связей и трансформация массива в комплексную отрасль законодательства может быть осуществлена с помощью систематизации. Под систематизацией законодательства при этом понимают «деятельность по приведению нормативных правовых актов в единую, упорядоченную систему» ${ }^{1}$.

Известно, что начиная с 60-х - первой половины 70-х гг. XX в. ученые говорили об использовании информационных технологий в различных

\footnotetext{
${ }^{1}$ Пиголкин А. С. Систематизация законодательства в Российской Федерации / под ред. А. С. Пиголкина. СПб., 2003. С. 30.

(C) Иванцова Ю. Г., 2020
} 
областях юридической деятельности. В тот период интерес исследователей был сосредоточен на изучении информационного обеспечения механизма государственного управления, развитии автоматизированных систем управления, использовании кибернетических методов и вычислительной техники в сфере юридической деятельности, а также в правотворчестве и при реализации (применении) права, отдельных видов последней ${ }^{2}$. В настоящее время уже не для кого не новы идеи о существовании «виртуального» государства ${ }^{3}$.

В настоящее время информационно-коммуникационные технологии внедрены во все сферы жизнедеятельности белорусского общества. Не осталась в стороне и юридическая деятельность. В Республике Беларусь функционируют различные информационно-правовые системы (далее ИПС) правовой информации, внедрены иные информационные технологии, которые оказывают влияние на систематизацию информационного законодательства Республики Беларусь.

ИПС правовой информации являются «необходимым инструментом в процессе деятельности по систематизации нормативных правовых актов» ${ }^{4}$. Наиболее известными в Республике Беларусь являются: ИПС «ЭТАЛОН», «ЭТАЛОН-ONLINЕ» (Национальный центр правовой информации Республики Беларусь (далее - НЦПИ)); «КонсультантПлюс» (ООО «ЮрСпектр»); АПС «Бизнес-Инфо» (ООО «Профессиональные правовые системы»); «Нормативка.bу» (ОДО «Профигруп») и др. И только правовая информация, содержащаяся в государственных информационно-правовых ресурсах и изданиях, является официальной (п. 25 Указа Президента Республики Беларусь от 30 декабря 2010 г. № 712 «O совершенствовании государственной системы правовой информации $\mathrm{Pe}$ спублики Беларусь») систематизации необходимо использовать эталонный банк данных правовой информации Республики Беларусь (далее - ЭБДПИ Республики Беларусь), распространяемый в ИПС «ЭТАЛОН-ONLINE» и ИПС «ЭТАЛОН» (версия 6.8).

В данной статье рассмотрим отдельные информационные технологии, используемые в Республике Беларусь при систематизации информационного законодательства, под которыми будем понимать «совокупность процессов, методов осуществления поиска, получения, передачи, сбора, обработки, накопления, хранения, распространения и (или) пре-

${ }^{2}$ См.: Керилов Д. А. Кибернетика и право // Советское государство и право. 1962. № 11. С. 98-104; Кнапn B. О возможности использования кибернетических методов в праве / пер. с чешского М. П. Лебедева. М., 1965 ; и др.

${ }^{3}$ См.: Старилов Ю. Н. Модернизация Российского государства и улучшение качества административно-правового регулирования в области защиты прав и свобод человека и гражданина // Право и государство. 2013. № 2 (59). С. 67.

${ }^{4}$ Шельленков В. Н. О систематизации законодательства с использованием информационных правовых систем // Государство и право. 2016. № 8. С. 99.

5 ЭТАЛОН. Законодательство Республики Беларусь / Нац. центр правовой информ. Республики Беларусь. Минск, 2019. 
доставления, использования» ${ }^{6}$ правовой информации в информационной сфере. Среди них:

- поисковый навигатор;

- Единый правовой классификатор Республики Беларусь (далее ЕПК Республики Беларусь);

- Свод законов Республики Беларусь (в электронной форме);

- Словарь юридических терминов на белорусском, русском и английском языках (далее - Словарь юридических терминов).

Поисковый навигатор. В настоящее время данный «инструмент» имеет название «поисковый навигатор» и доступен для использования в составе ИПС «ЭТАЛОН». О. О. Полещук отмечает, что поисковый навигатор представляет собой информационно-поисковый ресурс, призванный обеспечить оптимизацию поиска, навигацию в информационном массиве указанной выше ИПС и индексирование правовых актов при их юридической обработке 7 . При исследовании данной информационной технологии нами были инициированы внесения изменений в содержание данного инструмента, и разработчиками поискового навигатора добавлены в него следующие тематические группы (дескрипторы):

1) «информационно-коммуникационные технологии» (далее - ИКТ);

2) «международные информационные отношения», включающие правовое регулирование: в области связи (электрической, почтовой); в области доступа и обмена информацией; по вопросам пресечения обращения порнографических изданий; по вопросам обеспечения международной информационной безопасности; в области информатизации и информационных технологий и пр.;

3) «сотрудничество стран СНГ в информационной сфере», включающее правовое регулирование по вопросам сотрудничества стран СНГ в области: создания совместных органов в информационной сфере; информатизации, создания и использования информационных систем, сетей; связи (электрической, почтовой); книгоиздания, полиграфии, периодической печати, фильмопроизводства; средств массовой информации, рекламы; защиты информации, обеспечения информационной безопасности.

Таким образом, после вышеизложенных внесенных изменений можно констатировать, что поисковый навигатор системы «ЭТАЛОН» в действующем на сегодняшний день виде не противоречит выделенным нами ранее частям информационного законодательства Республики Беларусь ${ }^{8}$

${ }^{6}$ Об информации, информатизации и защите информации : закон Республики Беларусь от 10 ноября 2008 г. № 455-3 (в ред. от 11.05.2016) // ЭТАЛОН. Законодательство Республики Беларусь / Нац. центр правовой информ. Республики Беларусь. Минск, 2019.

${ }^{7}$ См.: Полешук О. О. Некоторые вопросы использования информационно-поискового тезауруса в задачах информационного поиска // ЭТАЛОН. Правоприменительная практика Республики Беларусь / Нац. центр правовой информ. Республики Беларусь. Минск, 2019.

${ }^{8}$ Ранее нами во внутренней структуре информационного законодательства Республики Беларусь были выделены следующие структурные части: законодатель- 
и может быть инструментом при систематизации в форме (виде) инкорпорации, консолидации, кодификации информационного законодательства Республики Беларусь.

EПК Республики Беларусь. Автоматизированный учет нормативных правовых актов осуществляется с помощью многоуровневого ЕПК Республики Беларусь, который утвержден Указом Президента Республики Беларусь от 4 января 1999 г. № 1 и представляет собой систематизированный массив правовых актов, отражающий «предметное и отраслевое деление нормативных правовых актов, составляющих законодательство Республики Беларусь (иерархическое строение классификатора)» ${ }^{9}$.

Как отмечает А. С. Пиголкин, классификатор является одной из методологических основ систематизации и кодификации законодательства, важным инструментарием, без которого невозможна эффективная законодательная деятельность. Он не только позволяет получать достаточно полную и точную информацию о правовых актах, но и способствует наведению должного порядка в их систематизации ${ }^{10}$.

Подробный анализ ЕПК Республики Беларусь показал следующее:

1) информационное законодательство не выделяется в отдельную группу в отличие, например, от жилищного законодательства, законодательства о здравоохранении и др.;

2) нормативные правовые акты, регулирующие отношения в информационной сфере, рассредоточены по различным рубрикам ${ }^{11}:$ законодательство в области лицензирования деятельности по технической и (или) криптографической защите информации (04.01.03.16); законодательство по вопросам архивного дела («Архивы. Архивные фонды» - 10.03.04); законодательство в области делопроизводства («Документоведение. Делопроизводство» - 10.03.05); законодательство о связи (04.12); законодательство об информащии, информатизации и защите информации (10.03); законодательство в области общих вопросов безопасности государства (государственные секреты (12.02.02)); законодательство о международном сотрудничестве в области информации, информатизации, связи и телекоммуникаций (16.03.10) и пр.

Представляется, что основным направлением совершенствования национального законодательства (в том числе и при проведении систе-

ство об ИКТ; законодательство, регулирующее правовые режимы информации; законодательство, регулирующее информационную деятельность субъектов; законодательство, регулирующее защиту информации и обеспечение информационной безопасности; законодательство, регулирующее международные информационные отношения (более подробно см.: Иванцова Ю. Структура информационного законодательства Республики Беларусь // Юстищия Беларуси. 2016. № 10. С. 76-79).

${ }^{9}$ Гриневич М. Г. О роли Единого правового классификатора Республики Беларусь в формировании национальной системы законодательства // Право.by. 2010. № 1. C. 9.

${ }^{10}$ См.: Пиголкин А. С. Систематизация законодательства в Российской Федерации. С. 159.

${ }^{11}$ См.: Информация по состоянию на 01.09.2019. 


\section{Вестник ВГУ. Серия: Право}

матизации) является сближение информационного законодательства и информационного права. Н. В. Сильченко считает, что классификатор должен быть результатом «наложения» отраслевой структуры законодательства на отраслевую структуру права и быть приближенным при этом к сложившимся отраслям государственного управления, поскольку основная масса нормативных правовых актов издается по сферам государственной власти и управления ${ }^{12}$. Взяв за основу данную позицию Н. В. Сильченко, отметим следующее.

Во-первых, при совершенствовании и систематизации информационного законодательства Республики Беларусь следует исходить из его сближения в системно-структурном аспекте с информационным правом. В настоящее время такое сближение наблюдается через их общие правовые институты, что впоследствии необходимо отобразить в структуре ЕПК Республики Беларусь.

Во-вторых, комплекс нормативных правовых актов, помещенных в рубрику «законодательство об информации и информатизации», не охватывает все законодательство в информационной сфере, так как «нормативные массивы должны совпадать со сферой государственного управления» ${ }^{13}$. Поэтому помимо рубрики «законодательство об информации, информатизации и защите информации» информационное законодательство Республики Беларусь в полном объеме или частично должно включать в себя:

- законодательство в области государственной статистики;

- законодательство в области архивного дела; делопроизводства;

- законодательство о связи;

- законодательство в области общих вопросов безопасности государства (государственные секреты);

- законодательство о международном сотрудничестве в области информации, информатизации, связи и телекоммуникаций.

В то же время, несмотря на несовершенство структурного строения ЕПК Республики Беларусь, он может по праву считаться ориентиром совершенствования и систематизации информационного законодательства Республики Беларусь. ЕПК Республики Беларусь позволяет вычленить из всей массы действующих нормативных правовых актов объекты для

180 дальнейшей систематизации информационного законодательства по видовому критерию, объединенные общей сферой государственного управления - информационной. Кроме того, предметно-отраслевой критерий представленных в ЕПК Республики Беларусь нормативных правовых актов может послужить базой для дальнейшего деления (группировки) законодательства на структурные части.

Свод законов Республики Беларусь (в электронной фборле). Закон Республики Беларусь от 17 июля 2018 г. № 130-3 «О норматив-

${ }^{12}$ См.: Сильченко Н. В. Единый правовой классификатор Республики Беларусь : проблемы и перспективы // Юстыцыя Беларусі. 2008. № 1. URL: http://elib. bsu.by/handle/123456789/147437

${ }^{13}$ Сільчанка M. У. Тәорыя крыніц беларускага права. Гродна, 2012. С. 213. 
ных правовых актах» ${ }^{14}$ исключил из законодательства категории «свод законов» и «свод законодательства». Одновременно с этим законодатель поясняет, что полным систематизированным собранием актов законодательства в электронной форме является ЭБДПИ Республики Беларусь (п. 3 ч. 1 ст. 72 Закона № 130-3).

Таким образом, Свод законов - доктринальная категория и определяется как систематизированное с помощью инкорпорации собрание только законодательных актов, т. е. является непосредственным итогом инкорпорации. В ранее действующем Своде законов Республики Беларусь акты информационного законодательства (Законы Республики Беларусь, Декреты и указы Президента Республики Беларусь) были помещены в следующие главы: 4.8. - Законодательство о связи (48 актов), 10.3 Законодательство об информации и информатизации (42 акта), 12.1.2 Государственные секреты (11 актов), 16.23 - Международное сотрудничество по вопросам информации, информатизации, связи и телекоммуникаций $(244 \text { акта) })^{15}$. В Свод законов было включено около 345 актов, из названия которых следовало, что они регулируют информационные отношения, посвященные отдельным видам информации (коммерческой тайне, научно-технической информации и пр.), статистике и учету, средствам массовой информации, издательскому делу, рекламной деятельности и др. Таким образом, акты в информационной сфере в Своде законов представлены преимущественно из законов, которые, хотя и регулируют «наиболее типичные и устойчивые, ключевые, основные, основополагающие, наиболее важные общественные отношения» ${ }^{16}$ в информационной сфрере, но не охватывают все виды информационных отношений, поскольку максимальная доля правового регулирования информационных отношений приходится на подзаконные акты.

Полагаем, что Свод законов Республики Беларусь (в его прежней форме) мог бы все-таки играть роль ориентира при кодификации информационного законодательства Республики Беларусь (при которой необходимо учитывать не только специальные акты в информационной сфере, но и нормы других отраслей права), а для других видов систематизации (инкорпорации и консолидации), объектом которых является весь массив законодательства, играл бы второстепенную роль.

Словарь юридических терлинов. При осуществлении систематизационной деятельности следует уделять пристальное внимание единообразию понятий и дефиниций. В настоящее время интенсивное развитие информационного законодательства в Республике Беларусь порождает некоторые проблемы такого свойства. Например, нередки случаи полисемии; отсутствуют определения родового понятия, в то же время видовые понятия присутствуют; наблюдается несоответствие «смыслово-

14 ЭТАЛОН. Законодательство Республики Беларусь / Нац. центр правовой информ. Республики Беларусь. Минск, 2019.

${ }^{15}$ Информация по состоянию на 12.10.2018.

16 Проблемы законотворчества и развития правовых систем / под ред. Н. В. Сильченко. Гродно, 1997. С. 4. 


\section{Вестник ВГУ. Серия: Право}

го наполнения» понятий, подмена понятий, встречаются случаи терминологической синонимии и т. п. Следует отметить, что при использовании юридической терминологии в текстах нормативных правовых актов необходимо руководствоваться общим принципом «стабильности терминологии и устойчивости принятых обозначений» ${ }^{17}$.

По данному поводу В. А. Шаршун и М. Г. Гриневич отмечают, что «унификация юридической терминологии является одним из важнейших средств обеспечения единого информационно-правового пространства Республики Беларусь, используемого нормотворческими органами при подготовке проектов правовых актов, и важным средством обеспечения единства употребления юридической терминологии не только в рамках одного нормативного правового акта, но и всей соответствующей отрасли законодательства» ${ }^{18}$.

Для разрешения проблемы «терминологической неточности» при формировании комплексной отрасли информационного законодательства в Республике Беларусь создан «Словарь юридических терминов». Указанный ресурс представлен в ИПС «ЭТАЛОН» как самостоятельный ресурс в отдельной вкладке, а также имеется его интернет-версия, размещенная на Национальном правовом интернет-портале Республики Беларусь ${ }^{19}$. Каждая позиция многоязычного словаря, помимо термина, представленного на белорусском, русском и английском языках, отражает его смысловые (ассоциативные) связи с иной терминологией ресурса, что позволяет получить представление об его месте в системе иных терминов с учетом имеющихся взаимосвязей ${ }^{20}$.

Таким образом, использование Словаря юридических терминов помимо поисковой функции при проведении систематизации позволит:

- решить проблемы терминологической неточности и неоднозначнотельства, а также выявить ее внутренние противоречия;

- определить системные связи между различными терминологическими единицами.

Итак, использование информационных технологий при систематизации информационного законодательства Республики Беларусь упрощает и облегчает трудоемкую систематизационную деятельность и позволяет наиболее полно выявить проблемы качества нормативных правовых ак-

${ }^{17}$ Сільчанка М. У., Сядзельнік В. В., Жаўняровіч С. А. Агульная тэорыя права : навуч. дапам. / пад рэд. М. У. Сільчанкі. Гродна, 2004. С. 185.

${ }^{18}$ Шаршун В. А., Гриневич М. Г. Многоязычный словарь юридических терминов как инновационный терминологический информационно-правовой ресурс // Право.by. 2011. № 3. С. 147.

${ }_{19}$ См.: Браусов А. М., Спивак О. И. Информационно-коммуникационные технологии в терминологическо-лингвистическом обеспечении юридической деятельности : опыт Национального центра правовой информации Республики Беларусь // ЭТАЛОН. Правоприменительная практика Республики Беларусь / Нац. центр правовой информ. Республики Беларусь. Минск, 2019.

${ }^{20}$ См.: Там же. 
тов. Являясь инструментально-прикладными, при систематизации они решают следующие задачи:

- отбор и анализ нормативных правовых актов в информационной сфере, подлежащих систематизации, а также выявление предметно-функциональных связей как между частями информационного законодательства, так и между отдельными структурными частями нормативных правовых актов (поисковый навигатор; ЕПК Республики Беларусь; Свод законов Республики Беларусь в электронной форме);

- устранение терминологической неточности, неоднозначности понятийного аппарата будущей комплексной отрасли информационного законодательства Республики Беларусь и выявление системных связей между различными терминологическими единицами (Словарь юридических терминов).

Институт повышения квалибикаиии и переподготовки кадров учреждения образования "Гродненский государственный университет илени Янки Купальз"

Иванцова Ю. Г., магистр юридических наук, старший преподаватель

E-mail: bonchuk_julia@mail.ru
Yanka Kupala State University of Grodno Institute for Professional Skills Upgrading and Retraining

Ivanzova Yu. G., Master of Legal Sciences, Senior Lecturer

E-mail: bonchuk_julia@mail.ru 